Abstracta Iranica Iranica

Revue bibliographique pour le domaine irano-aryen

Volume 24 | 2003

Comptes rendus des publications de 2001

\title{
"The Hanābila and the Early Sufis ». Arabica, XLVIII, 3 (2001), pp. 352-367.
}

\section{Denise Aigle}

\section{(2) OpenEdition}

1 Journals

\section{Édition électronique}

URL : http://journals.openedition.org/abstractairanica/34544

DOI : 10.4000/abstractairanica.34544

ISSN : 1961-960X

Éditeur :

CNRS (UMR 7528 Mondes iraniens et indiens), Éditions de l'IFRI

\section{Édition imprimée}

Date de publication : 15 mai 2003

ISSN : 0240-8910

\section{Référence électronique}

Denise Aigle, " «The Hanābila and the Early Sufis ». Arabica, XLVIII, 3 (2001), pp. 352-367. », Abstracta Iranica [En ligne], Volume 24 | 2003, document 177, mis en ligne le 05 janvier 2010, consulté le 25

septembre 2020. URL : http://journals.openedition.org/abstractairanica/34544 ; DOI : https://doi.org/ 10.4000/abstractairanica.34544

Ce document a été généré automatiquement le 25 septembre 2020.

Tous droits réservés 


\section{« The Hanābila and the Early Sufis ». Arabica, XLVIII, 3 (2001), pp. 352-367.}

\section{Denise Aigle}

1 Dans cet article, l'auteur tente de retracer l'origine des relations, à Bagdad, entre les premiers hanbalites et les adeptes d'un soufisme ascétique naissant. Appuyé sur une riche documentation de sources primaires et secondaires, l'auteur ne prétend pas atteindre la certitude qu'il existait un lien fort entre les premiers soufis et leurs contemporains hanbalites. Ahmad b. Ḥanbal, en dépit de sa piété personnelle et de sa croyance au pouvoir des reliques (il possédait une bourse qui contenait deux cheveux du Prophète), n'était proche d'aucun des «proto-soufis ». Il était même hostile à une pratique importante du soufisme, le dikr. Il semble que c'est plutôt vers la fin du $9^{\mathrm{e}} \mathrm{s}$. que le hanbalisme se rapprocha du milieu des soufis, en particulier avec Abū Muhammad al-Barbahārī, un disciple d'al-Marrūdī, le successeur d'Aḥmad. Cet article apporte de nouvelles informations sur la vie religieuse à Bagdad entre les $8^{\mathrm{e}}$ et $10^{\mathrm{e}} \mathrm{s}$.

INDEX

Thèmes : 8 . Soufisme 
AUTEURS

DENISE AIGLE

IFEAD - Damas 